\title{
Velas e Velones: sobre estética e materialidade entre Catolicismo e Vodu na República Dominicana
}

VICTOR MIGUEL CASTILLO DE MACEDO

\author{
A chama da vela que reza \\ Direto com santo conversa \\ Ele te ajuda te escuta \\ Num canto colada no chão mas sombras mexem \\ Pedidos e preces viram cera quente \\ Reza Vela - O Rappa
}

\section{Introdução}

$\mathrm{Na}$ quarta-feira de cinzas do carnaval de 2017 , no dia $1^{\circ}$ de março, eu tive a oportunidade de conversar com o então pároco da Igreja de San Miguel na capital dominicana, Santo Domingo. Naquele encontro, o padre Fray Francisco ${ }^{1}$ foi muito receptivo e me relatou parte de sua chegada à paróquia de San Miguel, precisamente como foi bem recebido pelos fiéis. O padre fez questão de ressaltar sua boa relação com todos os tipos de fiéis, mesmo aqueles que acreditavam em "coisas exteriores" à igreja católica. Explicou também que sua preocupação maior era, na verdade, com as intenções colocadas e os pedidos de intercessão a San Miguel, para situações que a seu ver não mereciam a atenção do santo. Os pedidos a que ele se refere podem ser escritos e depositados numa urna próxima a uma das imagens do santo na parte exterior da igreja, ou podem ser feitos em forma de orações, materializados nas velas acendidas e postadas também na parte de fora do templo. A exterioridade que aparece na fala de Fray Francisco tomou forma de oposição, meses depois, quando a Festa de San Miguel ocorreu no dia 29 de setembro de 2017.

1 Optei por ocultar o nome dos interlocutores devido à intensa atividade pública que alguns deles exercem no meio do vodu e das religiosidades populares dominicanas. 
O presente trabalho é uma exploração dos diferentes movimentos humanos e não-humanos observados nas comemorações do dia de San Miguel, em Santo Domingo. É a essa potencialização dos conflitos entre praticantes de vodu dominicano e católicos que me atentarei na primeira parte do texto, procurando evidenciar de que se vale esta oposição e quais são suas durações. Na segunda parte, descrevo com fotografias e relatos o que vi na festa a San Miguel daquele ano. As velas que aparecem nas imagens em comemorações ligadas ao vodu ou nas dependências da igreja vão compondo uma paisagem comum e em constante transformação. Na terceira parte, volto-me com mais cuidado às velas e ao que elas podem fazer em termos de circulação. Exploro a diversidade de papéis que elas cumprem tanto em ambientes dedicados ao vodu, quanto no catolicismo. Minha intenção é sugerir que a articulação de objetos/coisas, cores e formas nos distintos ritos brevemente descritos seja mais que mero detalhe formal. Essas variações informam, conforme as compreendo, a própria dinâmica de oposições por meio de um viés estético/ético, que localiza as velas como coisa-conceito dentro da cosmologia do vodu.

Assim, não pretendo apresentar um argumento final com respeito a estas relações inter-cosmológicas, mas sim demonstrar que a atenção a esses objetos/coisas informa e pode abrir novos direcionamentos sobre o vodu dominicano e sobre o catolicismo popular no país. Quando afirmo tal "novidade", me coloco no mesmo sentido de trabalhos recentes sobre expressões cosmológicas afro-caribenhas (privilegiando questões ligadas à materialidade e à transformação), e de modo discreto, sobre o vodu, como o trabalho de Alline Cruz (Cruz 2014). Não se trata, portanto, de um levantamento crítico da bibliografia dominicana sobre o vodu, mas da sugestão de outros caminhos, a partir de um olhar sobre elementos que compóem as práticas reunidas sob tal rubrica. Certamente, com as escolhas feitas para este texto, muitas questões receberão uma atenção marginal - o que, por outro lado, me faz evitar caminhos já trilhados e reforçados por autores clássicos da literatura caribenha, como Alfred Métraux (1958), Mélville Herskovits (1971) e Jean Price-Mars. (1953).

Ao final do texto, exploro de maneira mais clara o que considero serem os transbordamentos do âmbito discreto das velas. Pontuo, entre outras coisas, possíveis continuidades entre o mundo feito a partir das velas do vodu dominicano e a cosmologia católica-nacionalista.

\section{Controles e constâncias}

Abordar a relação entre catolicismo e o conjunto de práticas sob o nome de vodu é aparentemente um lugar comum na bibliografia dominicana (para citar alguns dos trabalhos mais conhecidos: Deive (1988); Davis (1996); Tejeda Ortiz (2013); Andújar (2007)²). No entanto, para evitar as extensas descrições nas quais os autores citados acabam caindo ao enumerar semelhanças e diferenças mais ou menos históricas entre os âmbitos em questão, opto aqui por retomar a descrição etnográfica do início deste texto e falar mais sobre o Fray Francisco e o que pude apreender de sua relação com praticantes

2 É importante atentar de que o que chamo de Vodu Dominicano são os conjuntos de práticas que advêm do lado oeste da ilha - o Haiti. Portanto, se trata de uma expressão afro-caribenha. Apesar de o Haiti ser um país de evidente maioria negra em sua população, não se pode deixar de lado que esse fato se repete na República Dominicana com menor efeito demográfico. O modo de escrita do termo, Vodu, segue aqui o trabalho pioneiro de Carlos Deive (1988) e da antropóloga Martha Ellen Davis (1996), que me parecem mais próximos do uso na língua espanhola falada, embora outros trabalhos tendam a usar "vudú". Nas pesquisas sobre o Haiti, se encontram também Vodoun, Vadou ou Voudu. 
do vodu. O pároco da igreja de San Miguel, durante minha primeira estada em campo (janeiro a março de 2017), explicou quando conversamos que ao longo da novena para San Miguel - realizada todos os anos durante o mês de setembro - do ano anterior, recebeu diferentes ideias de moradores do bairro. Especificamente, a ideia de um deles, Lucas, um praticante de "crenças externas" - como colocou o padre -, foi acatada e contribuiu para aumentar o movimento do dia da festa. Lucas havia sugerido que um grupo de Mariachis (cantores de música tradicional mexicana) ${ }^{3}$ tocasse a partir da meia noite do dia 28 de setembro.

A festa de 2016 havia marcado muitas pessoas como uma das mais movimentadas, uma vez que a festa de San Miguel é sempre citada como a segunda maior festa popular de cunho religioso, atrás apenas da festa de Nossa Senhora de Altagracia, padroeira do país. No entanto, o senhor Pablo ${ }^{4}$, um produtor cultural e morador da região, me explicou que ao final da festa "muitas pessoas alcoolizadas e, provavelmente, sob o efeito de outras substâncias circulavam pelas ruas do Bairro de San Miguel". O mesmo senhor me contou que no ano passado as pessoas passaram dos limites e havia inclusive "jovens homossexuais se beijando na rua”. Foi aí que a polícia interveio, com razão - segundo ele. As forças policiais foram acionadas no final da noite, início da madrugada do dia 30, quando a igreja já estava fechada há algum tempo (pois a última das seis missas do dia é às 22 horas). Ouviram-se tiros que soavam como fogos de artifício para quem estava longe do local da festa, conforme me descreveu a antropóloga Sandra ${ }^{5}$, que a essa hora estava em casa, na zona colonial de Santo Domingo.

Lucas, servidor de mistérios que divide sua vida entre estadas em Nova Iorque e em Santo Domingo, é dono de uma casa em frente à igreja e é responsável por organizar uma das festas, talvez a maior delas, dedicadas a San Miguel nas imediações da igreja ${ }^{6}$. Conforme Lucas explicou, o investimento era muito grande, contando com importantes cantores da música popular dominicana e uma produção que fosse digna de "Belié Belcan”. Esse é o nome do mistério, ou lwa (Luá ou Loa), que, como a literatura e os servidores explicam, é apadrinhado por San Miguel. Celebrar San Miguel é celebrar Belié Belcan, apesar de nem todos os devotos compartilharem desse entendimento. Enquanto servidor, Lucas é devoto de San Miguel e recebe a Belié Belcan como cavalo. Aliás, ele e todas as outras pessoas que conheci, que direta ou indiretamente praticam o vodu dominicano, iam às missas na igreja de San Miguel. Belié Belcan é o mistério mais querido em nível nacional, chamado de "el viejo". Apesar de casado com Anaísa Pié (Santa Ana, a quem Lucas também recebe), ele encanta outras mulheres, tem várias namoradas, gosta de festas, rum e tabaco.

$\mathrm{Na}$ festa de 2016, como Lucas me contou, havia tantas pessoas que o chão em volta da igreja estava coberto de velas de todas as cores e tamanhos, mas principalmente velones - que são velas de sétimo

3 Os Mariachis são grupos geralmente compostos de três tipos de violão. No entanto, neste contexto, a única associação possível da presença deles é compreensível pela imagem de Nossa Senhora de Guadalupe - padroeira do México, ao lado da imagem de San Miguel ao fundo da igreja (ponto que não exploro neste texto). Sobre a relação entre nacionalidade e a Virgem de Guadalupe, ver Eric Wolf (1958). 4 Eu o conheci através de meu pai, que também é dominicano.

5 Mais adiante ficará claro que Sandra foi uma interlocutora muito importante na minha introdução ao mundo das práticas do vodu dominicano.

6 O servidor de mistérios do Vodu dominicano é uma figura que lembra os pais e mães de santo do Candomblé e da Umbanda. Isso porque recebem os santos/mistérios e por isso são conhecidos também como cavalos, ou seja, os mistérios montam eles. São servidores porque não recebem pelo trabalho que exercem e pode-se dizer que servem também aos mistérios, alimentando-os em seu cotidiano. No entanto, diferentemente do Candomblé e da Umbanda, seus trabalhos não ocorrem em terreiros específicos. 
dia de cores variadas, incluindo o branco - verdes ou vermelhos. Apesar da igreja católica só considerar as velas brancas como apropriadas aos pedidos e orações, na igreja de San Miguel são aceitas velas nas cores do mistério. Parece haver assim um modo cromático de diferenciação entre essas cosmologias - as velas brancas pertencem àqueles católicos que não querem demonstrar relações com o vodu; os velones coloridos denotam uma relação confortável com a possibilidade de ser identificado como praticante de vodu. Antes de explorar como as velas e os velones transpõem essas fronteiras, aqui colocadas de modo mais simplificado, parece-me necessário qualificar melhor de que forma a Igreja Católica dominicana se posiciona ou se posicionou historicamente em relação às práticas voduístas.

Não é o caso de se produzir uma lista de semelhanças e diferenças cosmológicas/ritualísticas, mas sim de se tomar alguns fragmentos do passado que possam operar como imagens que explicitam as durações ou permanências - conforme sugerido por Marilyn Strathern (Strathern 2014:215). Logo, a primeira delas pode ser o projeto contido no Código Negro Carolino de 1784 (Barceló 1974) - redigido pelo então ouvidor Don Agustín Emparán de Santo Domingo (colônia) - que nunca chegou a ser aplicado pela metrópole espanhola. Aqui eu o tomo como um artefato que expressa a localização da igreja de San Miguel dentro do aparato colonial, por um lado, e da articulação que se estabeleceu entre Estado colonial e Igreja, por outro. Na parte do código dedicada ao governo moral (Capítulo 1), lê-se a respeito de cultos dos negros, na lei 2 :

Proibimos por esta razão sob as mais severas penas, as noturnas e clandestinas reunióes que costumam se formar nas casas dos que morrem, ou de seus parentes a orar e cantar em seus idiomas para honrar o defunto com mescla de seus ritos e de fazer as danças que comumente se chamam de Bancos, em sua honra e memoria com demonstraçôes e sinais indicadores do infame principio de que provém em muitas de suas castas, singularmente nos minas e carabalíes em que há o número, a saber, da methempsicosis ainda que adulterada, ou a transmigração das almas a sua amada pátria que é para eles o paraíso mais delicioso.

Pelo qual se deverá formar um breve tratado moral, dirigido a desterrar nos negros suas erróneas, mas bem arraigadas noções e ideias de divindade de sua pátria segundo suas diferentes castas que variam igualmente em seus ritos.(Barceló 1974:164). ${ }^{7}$

Da mesma forma, no capítulo 10, dedicado às "cofradías" - confrarias em português, grupos de devotos que se reuniam pela causa de um santo específico e que existem até hoje na República Dominicana - outros modos de controle aparecem. A preocupação expressa na introdução às leis é direcionada aos maus usos de vaidade que a expressão dessas devoções catolicizadas sofrem. As festividades passam a ser usadas para a celebração do corpo, das danças que podem durar dias e noites consecutivas. Don Agustín em suas recomendações sugere, na Lei 1 deste capítulo:

E sendo nosso ânimo cortar na raiz a prática de umas inclinações que bem dirigidas podem ser úteis a causa pública e a religião e a suavizar mais seus rústicos e grosseiros costumes, permitimos

7 Todas as citações em espanhol ou inglês foram traduzidas livremente pelo autor. 
que possam continuar as festividades e funções eclesiásticas que celebram em suas confrarias, restringindo somente a matéria pertencente ao culto exterior... (Barceló 1974:188).

É certo que o que o autor do código está chamando de "culto exterior" pode não ser exatamente a mesma coisa a que Fray Francisco se refere acima, mas a condição de exterioridade não confere somente uma característica de externalidade - ela diz respeito a um conjunto de práticas que não pertencem (nem podem pertencer) ao espaço católico. Aliás, a igreja de San Miguel aparece no código como um espaço passível de receber os festejos de confrarias, como se vê na lei 4 do décimo capítulo:

E para que as confrarias dos negros possam ser úteis a causa pública, fazendo com que se invista ao seu benefício parte dos caudais que se consomem em sua ruína, mandamos: Que sejam levados todos à Igreja de San Miguel nesta cidade, situada em terreno são e elevado... (Barceló 1974:189).

Não obstante a concentração das confrarias na igreja de San Miguel, o fato de ser uma igreja afastada do centro da cidade colonial permitiria que essa funcionasse também como hospital para os negros - na leitura de Emparán. Assim, como se pode ver, a atuação da Igreja na resolução de problemas de Estado era comum e, apesar dessa não ser uma novidade, retomar esse tipo de leitura me ajuda a situar ambas as instituições como parte da mesma empresa. Não obstante, são diferentes faces de uma mesma razão, ou mais especificamente, uma mesma ontologia - conforme Michel Rolph-Trouillot descreve (Trouillot 1995:76-77) - que se origina na renascença e nivela graus de humanidade ou graus de subjetividade. Em outras palavras, a empresa do colonialismo - que na experiência espanhola teve a articulação entre Estado e Igreja como um de seus principais eixos - operava também um tipo de encadeamento epistemológico no qual a subjetividade não ocidental (nesse caso a de africanos escravizados) foi sistematicamente esvaziada.

Apesar da análise do antropólogo haitiano se referir ao "silenciamento" sistemático que a história ocidental construiu em torno da revolução haitiana, não creio que um movimento esteja necessariamente desvinculado do outro. Certamente são tempos distintos, mas a relação com a população negra, as práticas e as cosmologias advindas do continente africano na ilha dividida por República Dominicana e Haiti é, grosso modo, a mesma. Tais práticas e ritos foram controlados e perseguidos continuamente por aparatos estatais e clericais, tanto no período colonial quanto no pós-colonial - eu retorno à leitura de Trouillot mais adiante.

Alguns exemplos recentes são trazidos pelo sociólogo Dagoberto Tejeda Ortíz (2013:92-93), quando remonta às denúncias sobre as cenas de imoralidade que se efetuavam nos bairros de Santa Bárbara e San Miguel, onde está a igreja - na análise de Emílio Rodriguez Demorizi sobre uma resolução de 1878, proibindo o "baile de palos". Na ocasião, a preocupação maior era a realização desses bailes em frente ao palácio arcebispal - e dela se desprendeu a proibição da reprodução dos toques de palos (tambores) nas proximidades de qualquer igreja. Apesar da perseguição ao vodu não ter a mesma força 
repressiva que teve no lado haitiano da ilha ${ }^{8}$, o par Estado-Igreja dominicano nunca se acomodou com as existências do vodu. É o que se vê no caso da lei 391 de 20 de setembro de 1943, que criminaliza as práticas relacionadas à "voudou" e "luá", em lugares públicos ou não, podendo caber a deportação da pessoa quando haitiana, e tendo como consequência a destruição dos objetos utilizados nos cultos (art.3) (Ortíz 2013:97). Desta forma, fica claro que o caráter de oposição que a relação entre estas cosmologias tem é no mínimo de longa duração.

O ponto a se destacar aqui é que, mesmo com uma contraposição que se constitui e permanece latente ao longo de séculos, o vodu não deixa de existir. Isso se dá porque não se trata de uma cosmologia que se formou em oposição ao catolicismo/Estado ou como observa Joan Dayan:

Vodou não se opõe ao que podemos chamar de "Ocidental" ou "Cristão" mas associa livremente elementos aparentemente irreconciliáveis, tomando materiais da cultura dominante mesmo quando resiste ou coexiste com ela. (Dayan 1995:51).

As práticas que correspondem a essa cosmologia, que pode ser considerada uma ontologia que habita a ilha de Ayti (ou Hispaniola), como tantas outras, não se limitam a ser uma expressão oposta ao cristianismo. No entanto, tal cosmologia é continuamente combatida, desmobilizada e afastada dos pilares institucionais dominicanos - sobretudo em termos de reconhecimentos legais do direito de ser praticada ou mesmo de existir.

Na festa de San Miguel de 2017, diversas mudanças ocorreram para que não houvesse espaço para os "desvarios" da festa popular. O primeiro acontecimento que marcou a festa de 2017 foi a transferência do Fray Francisco para outra paróquia (não consegui me informar sobre o paradeiro do padre) alguns meses antes da festa. Isso causou revolta entre um grupo de servidores de mistério que compõe a "Sociedad Dominicana 21 División San Miguel Arcangel", formada por aqueles que servem a San Miguel/Belié Belcan e o recebem em cerimônias de vodu nas imediações da igreja. Um dos principais servidores desta sociedade é Lucas - que em uma página de rede social deu declarações bem francas a respeito da saída do Fray Francisco:

8 No prefácio de "Le vodou haitien", Alfred Metraux expressa uma grande preocupação com a possibilidade real de desaparecimento das práticas do vodou no Haiti. Sobre o caso Haitiano e a relação entre vodou/Estado com mais detalhes e desenvolvimentos, ver Ramsey (2011).

$921^{a}$ División ou 21 División, se refere aos três grandes ramos do vodu dominicano - sete mistérios de origem católica/europeia (do qual San Miguel faz parte), sete mistérios de origem africana, sete mistérios de origem taína. 
Matam o Trujillo e depois dele não pode surgir outro igual... Não podemos permitir que implantem o que nos desagrada, que se aniquile o que já é tradição... nosso setor quer a procissão de San Miguel (...) (não podemos ficar calados ... queremos que o Fray fique)..$^{10}$

Outro elemento que aparece já na mensagem de Lucas é a decisão do arcebispado de não fazer a procissão com a imagem de San Miguel. Como afirmei acima, no ano anterior a festa estava muito cheia e, por isso, a procissão levou muito tempo para fazer todo o seu percurso. Essas decisões geraram um mal-estar muito grande, principalmente com aqueles servidores de mistérios que vivem na região do Bairro de San Miguel. Uma terceira questão apareceu como uma repetição de 2016 - as pessoas que foram para vender lenços, bebidas, charutos e/ou levar os bolos em oferenda a São Miguel foram afastadas do entorno da igreja - algumas ficaram na rua Juan Isidro Perez e outras na praça em frente à entrada principal da igreja, chamada parque San Miguel. Abaixo, um mapa da Zona Colonial mostra algumas das ruínas da primeira cidade das Américas no qual se pode observar a localização marginal da igreja de San Miguel em relação ao centro da cidade colonial, que estava mais próximo da costa. $\mathrm{O}$ desenho do mapa segue também o traçado dos muros da antiga cidade.

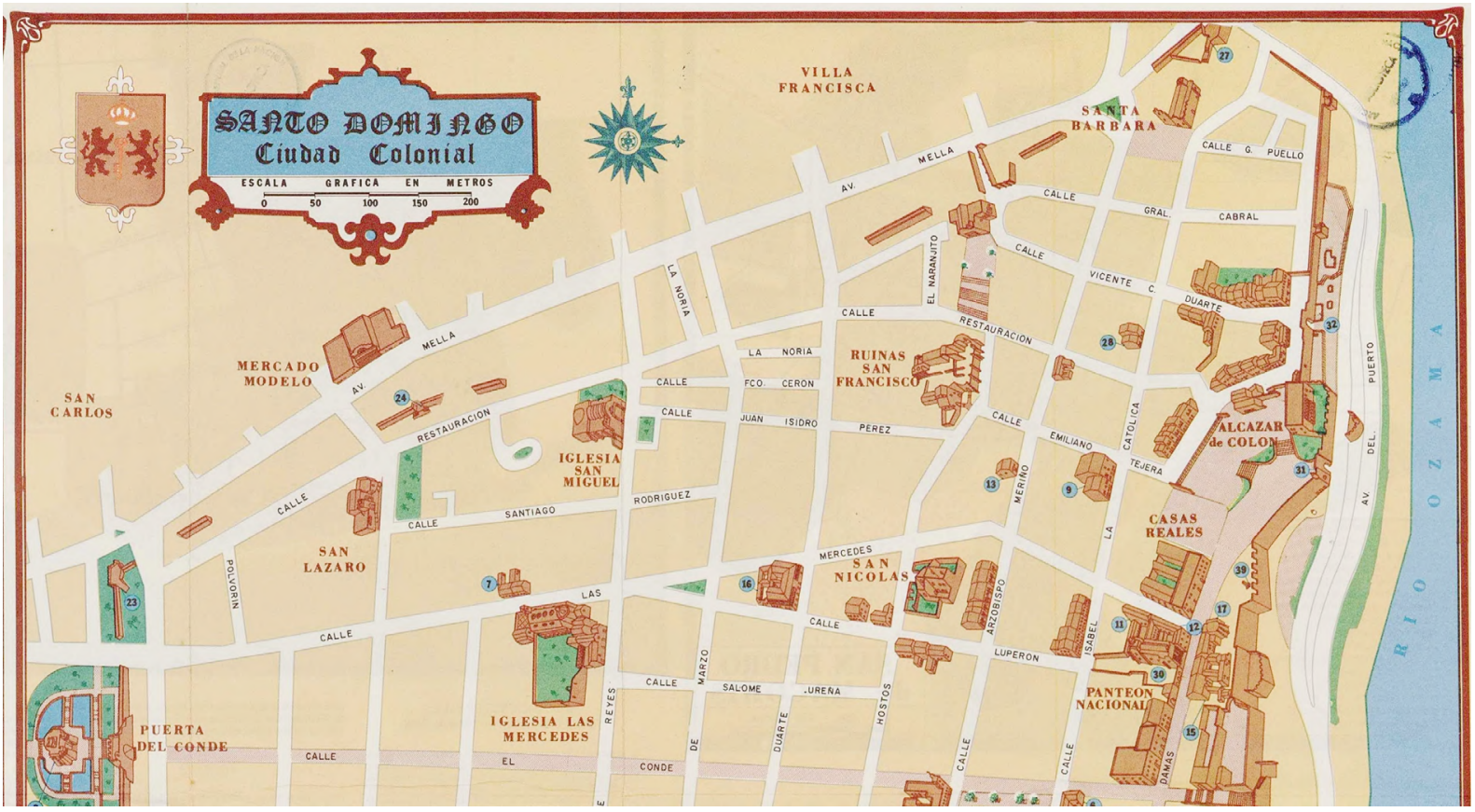

Imagem 1: Zona Colonial de Santo Domingo, mapa de comemoração do centenário da chegada de Colombo. Fonte: Archivo General de la Nación, 1992.

\footnotetext{
10 Quando Lucas se refere a Trujillo, está falando do ditador Rafael Leônidas Trujillo (1891-1961), que esteve no poder desde 1930 a 1961 mantendo uma situação de terror na vida política dominicana. Trujillo foi responsável, nos primeiros anos no poder, por uma relação próxima com a Igreja Católica. Nos anos finais de seu mando, membros da Igreja passaram a ter um papel importante na oposição ao regime - no entanto, pode-se dizer que o mal estar com o ditador era um sentimento comum na elite dominicana no mesmo período. A lei de 1943, elencada acima, é parte desse projeto de uma pátria católica que foi reforçado nos anos Trujillo. 'El Jefé, como era conhecido, foi responsável por uma série de reformas modernizadoras no Estado Dominicano. Antes de se tornar o líder máximo da nação dominicana, fez sua formação militar nos Estados Unidos, durante o período da primeira ocupação estadunidense (1916-1924). Apesar de modernizar o funcionamento do exército e da polícia dominicana, ele concentrava em si todos os elementos do conservadorismo do país: um homem branco, heterossexual, católico, militar. O ditador foi assassinado em 1961 graças a um complô que envolvia antigos aliados e inimigos que se acumularam ao longo de 30 anos no poder.
} 
Diante desse quadro de relações conflitivas, que ora se dilui, ora se torna tenso, o que permanece é a possibilidade de tensão em si. O fato de Lucas ter evocado esta poderosa e polêmica figura histórica que foi o ditador Trujillo para questionar/denunciar a arbitrariedade das autoridades demonstra como esta questão se atualiza. No entanto, é necessário considerar o que se passa na festa e como esse santo/ mistério contém e mobiliza poderes e hierarquias.

\section{A festa de San Miguel em 2017}

Para orientar este relato, me apoiarei em fotografias da festa que permitem outras interpretações e entendimentos.

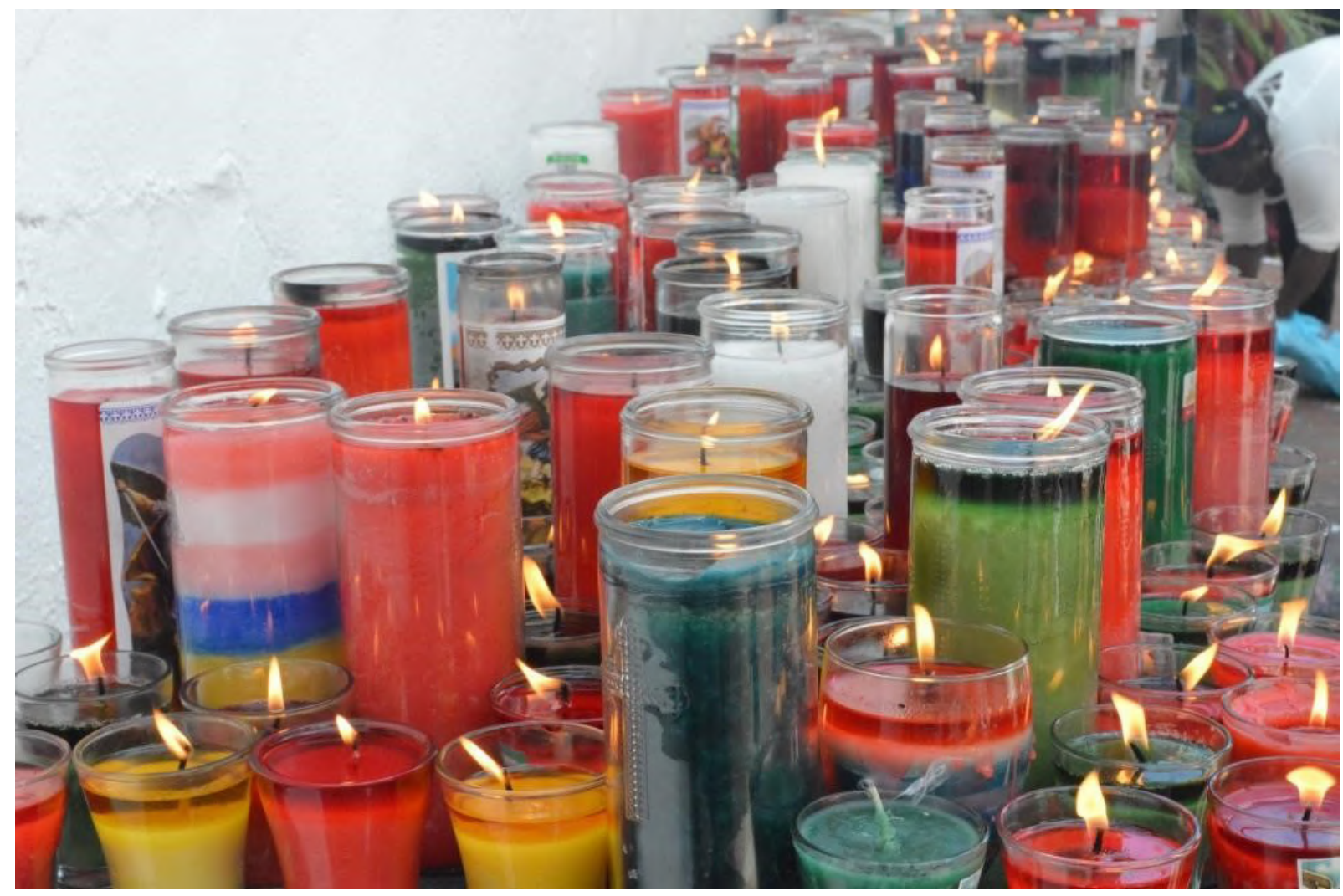

Foto 1: Velones para San Miguel na igreja. Fonte: Acervo do autor, 2017.

O aglomerado de velas ou velones que aparecem na Foto 1 parece ser uma das melhores formas de condensar os movimentos da festa de San Miguel. Uma festa de aglomerados. Pelo menos, nos imaginários e nas memórias, a forma de se referir ao evento é sempre superlativa - a maior festa popular, a festa mais cheia da capital, o dia mais quente do ano, o santo mais popular. Tudo é o máximo quando se refere a essa festa, que é sempre uma forma de explicar o que é San Miguel para as pessoas - o arcanjo mais forte, o líder do exército celestial e, principalmente, quem abre os caminhos e protege dos inimigos.

Assim, no dia 29 de setembro, eu me preparava de manhã cedo para o que seria um extenuante dia - e extenso sobretudo. Procurei chegar cedo à Zona Colonial, em torno das 9 horas da manhã - o que significa que não pude ir à primeira missa do dia, às 6 horas. No entanto, foi tempo suficiente para 
estar lá na missa das 10 horas (Foto 2), que era a primeira com uma grande aglomeração de pessoas assistindo. Nessa missa já havia muitas pessoas com roupas nas cores verde ou vermelha (cores de Belié Belcan), e a resposta do padre responsável (cujo nome não consegui obter) pela missa à indesejável presença foi um sermão muito duro e em tom de reprovação aos credos que não fossem dirigidos a Deus e a Jesus Cristo.

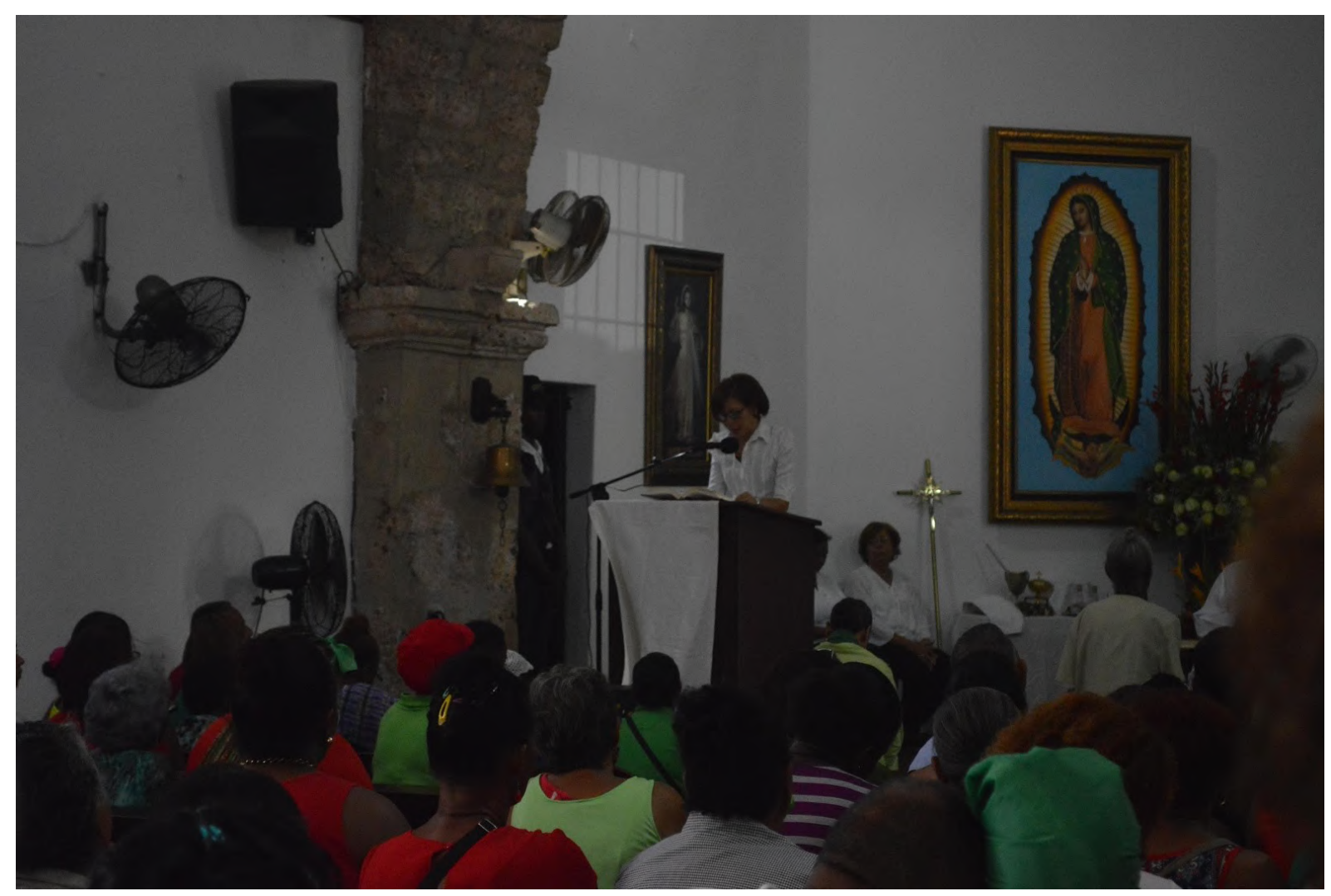

Foto 2: Segunda missa da manhã - primeira leitura. Fonte: Acervo do Autor, 2017.

A igreja, que não é muito grande, estava lotada e foi praticamente impossível entrar. Acabei ficando na lateral, junto com muitas outras pessoas que foram chegando depois de mim - todas tentando de algum jeito entrar ou estar mais próximas da parte interna da igreja. Ao fim dessa missa, encontrei a antropóloga Sandra que conheci no começo de 2017 na minha primeira ida a campo. Há anos ela vem documentando a festa e foi quem me passou as informações mais importantes sobre o que se produz para a festa. Ela me explicou que, provavelmente, devido ao furacão Maria e à ausência de procissão, muitas pessoas não viriam ao festejo daquele ano.

Enquanto começávamos a circular pelo pátio que forma uma praça ao lado da Igreja (a plaza San Miguel), víamos os militares com fardas e com trajes especiais que se preparavam para a missa das onze e meia, feita especialmente para o exército. É importante levar em conta que São Miguel é o patrono do exército dominicano. Antes que essa missa começasse, fui com Sandra até um pequeno prédio, próximo ao parque San Miguel (em frente à igreja). Lá, encontramos os últimos preparativos para uma pequena festa a San Miguel, feita em agradecimento a um pedido que foi atendido pelo santo (Foto 3 ). Nossa atenção nos levou até lá pelo aquecimento que estava sendo feito pelos paleros - ou tocadores 
de palo (tambores). Com sons muito distintos dos que acabáramos de escutar dentro da igreja, o ambiente, apesar de ser muito pequeno e escuro, atraía muitas pessoas. A organizadora da festa estava um pouco atrapalhada, pois faltavam os últimos detalhes para agradar a San Miguel/Belié Belcan, como, por exemplo, neste caso, o rum que estava no altar não era o mais apropriado, pois se tratava do rum tipo prata e somente runs de tipo ouro podem ser oferecidos ao santo.

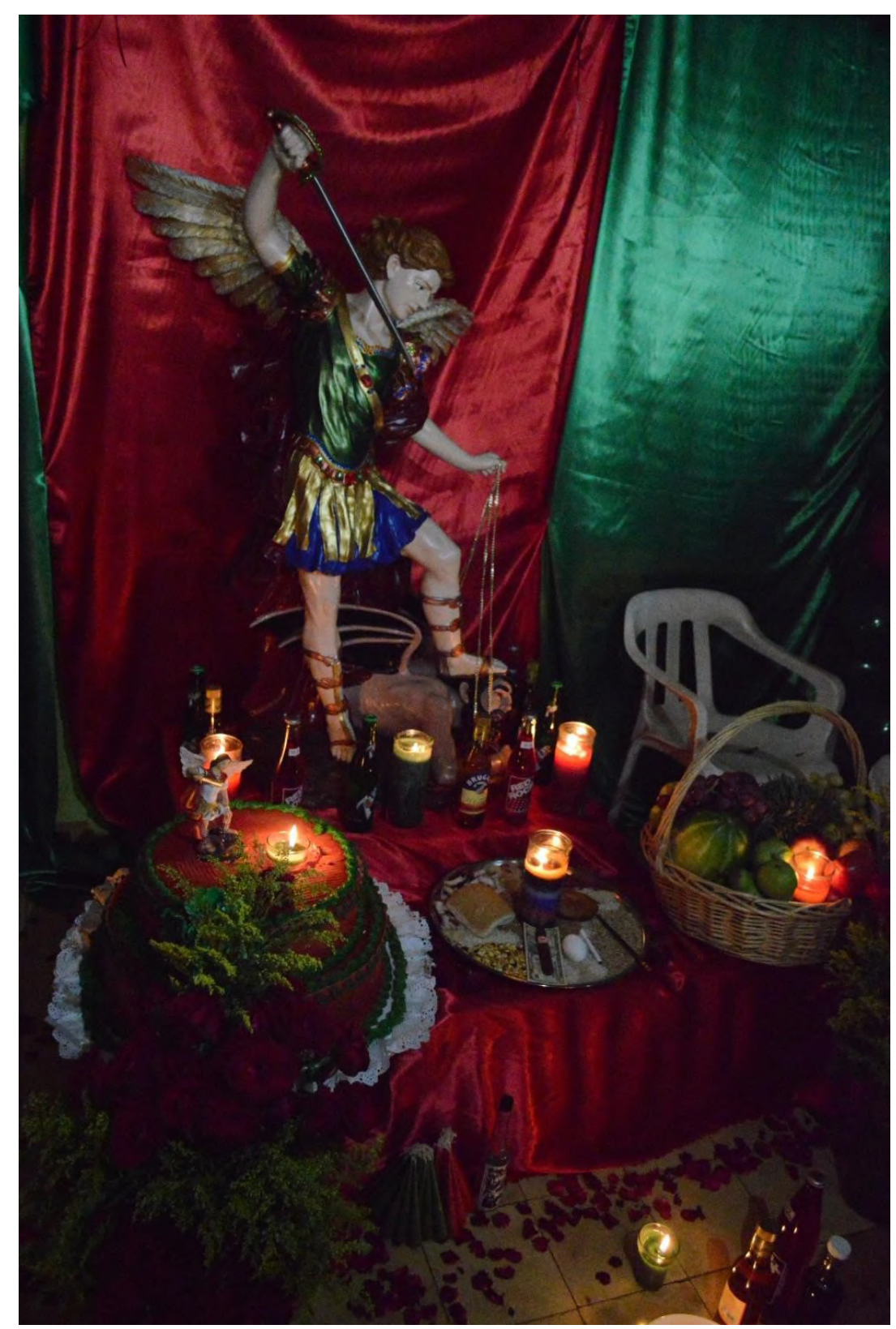

Foto 3: O altar da festa no pequeno prédio próximo à igreja. Fonte: Acervo do Autor, 2017.

A tensão de dentro da festa que estava começando também chegava ao lado de fora daquele pequeno apartamento, pois policiais militares circulavam com olhares atentos e cassetetes em mãos, procurando evitar qualquer tumulto (ou talvez produzi-lo). Na rua, porém, o movimento de pessoas aumentava consideravelmente, e agora já se viam mais pessoas com o colorido verde e vermelho em distintas formas. Muitos servidores de Belié foram vestidos com roupas especialmente feitas para a 
ocasião ${ }^{11}$, outros levaram bolos e pipoca para serem distribuídos. Do mesmo modo, as pessoas bebiam rum e fumavam charutos em homenagem a Belié Belcan, El viejo. Tudo isso porque esse mistério gosta muito das festas, mas manca, assim como San Miguel, pois sobreviveu ao ataque do diabo.

A difícil separação entre a imagem do mistério e a imagem do santo evidencia as contiguidades que se espelham até entre alguns dos mais fervorosos devotos de San Miguel - os membros das forças armadas do Estado e traficantes de drogas que atuam em Santo Domingo. Essa foi uma informação que obtive de segunda mão, pois foi Sandra quem me explicou. Segundo ela, é recorrente que se peça proteção a San Miguel, uma vez que ele é um santo guerreiro. Por outro lado, a concessão da autoridade do santo ao exército é parte do funcionamento do Estado dominicano e da sua aliança com a Igreja Católica.

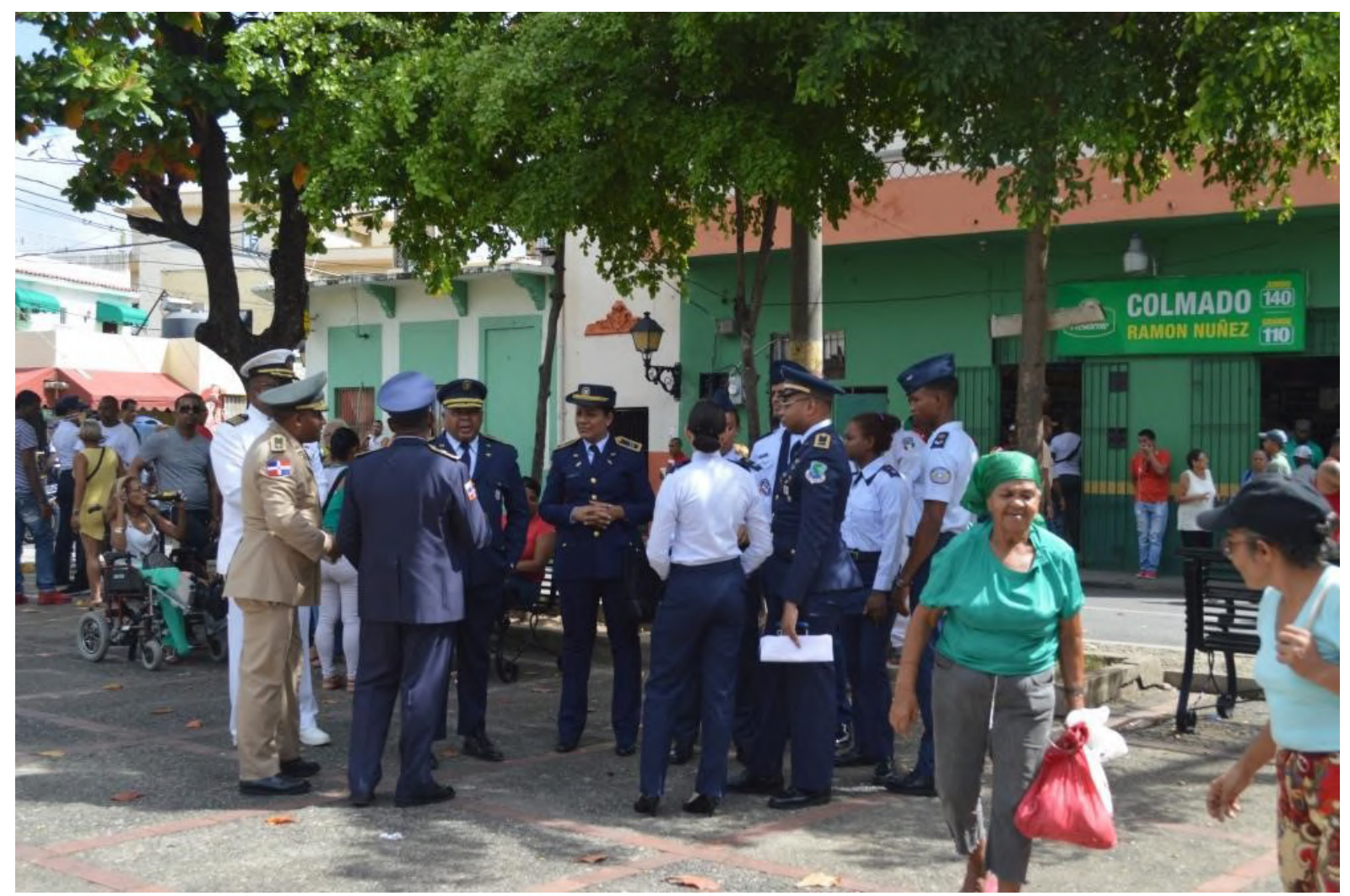

Foto 4: Membros do exército dominicano aguardam a missa na plaza San Miguel.

Fonte: Acervo do Autor, 2017.

A segunda missa a que fui naquele dia foi a dedicada aos militares, rezada pelo Monseñor Obizpo Jesus Castro Marte, bispo auxiliar do arcebispo de Santo Domingo, maior autoridade da Igreja dominicana e membro do exército, uma vez que o Estado dominicano é oficialmente católico e ao arcebispo cabe um enquadramento funcional militar. Monseñor Jesus fez uma missa menos demorada e menos direcionada às crenças "externas" - sobretudo, no seu sermão, optou por fazer uma defesa do amor de Cristo e da necessidade de o católico seguir seus ensinamentos. No entanto, a missa não per-

11 Não posso deixar de comentar como esse fator estético das roupas e panos na festa, ressoa parte da reflexão desenvolvida por Webb Keane (2005:200-201). Mais especificamente, como os signos só operam enquanto mediadores semióticos diante de ideologias semióticas historicamente específicas. Assim, uma pergunta que não pude responder é quando e como essas cores passaram a significar algo para os devotos do vodu dominicano. 
deu em intensidade. Muitos devotos de San Miguel se juntaram atrás dos lugares reservados para os militares e o movimento só aumentou, ao ponto de o corredor do meio estar, também, repleto de pessoas.

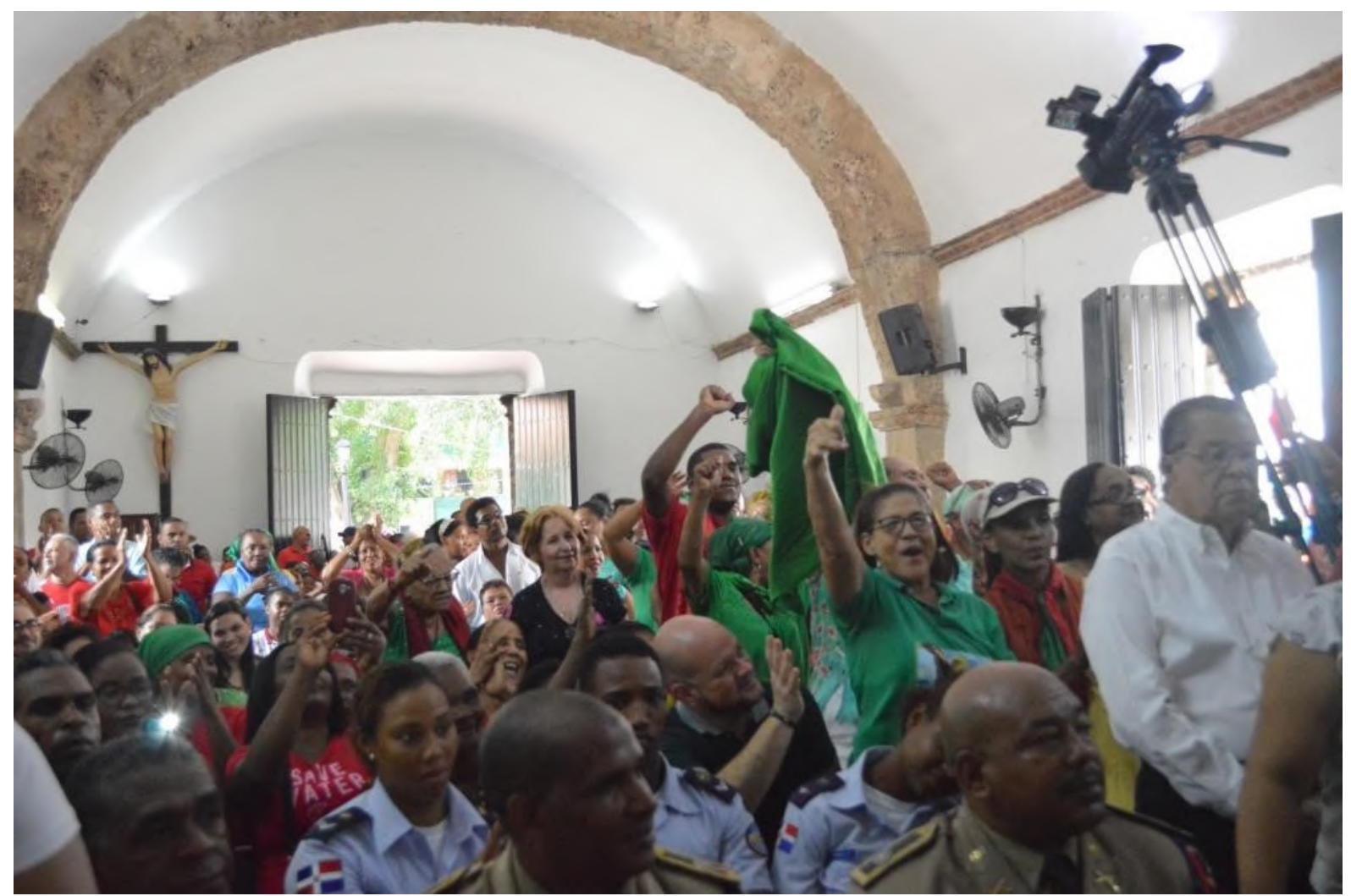

Foto 5: Devotas e devotos de San Miguel na missa para os militares. Fonte: Acervo do Autor, 2017.

Após essa celebração, a igreja fecharia suas portas até as missas da tarde e da noite. Quando saímos, o movimento no parque San Miguel havia diminuído. Nessa hora, decidimos almoçar, pois não havia muito o que ficar esperando. Havia alguns servidores de San Miguel em transe, atendendo pessoas, e muitas pessoas esperando outros bolos para o santo chegarem. A batucada da festa a que fomos ao meio da manhã ia e voltava constantemente e por isso muitas pessoas levaram suas garrafas de rum e seus charutos para as proximidades.

Aproveitei também para ver como estava o espaço para as velas na igreja - foi nessa hora que tirei a foto que abre essa seção. O verde e vermelho, tão comuns nas festas de vodu, feitas para o mistério Belié Belcán e que tomavam a rua e as praças, agora enfeitavam a igreja, entre luzes e ceras derretidas. Desde então, começaram a me chamar a atenção não só a quantidade de velas, mas o acesso delas àquele espaço externo/interno da igreja e as preocupações do antigo pároco do santuário. A segunda parte daquele dia me fez pensar mais cuidadosamente a respeito das velas. 


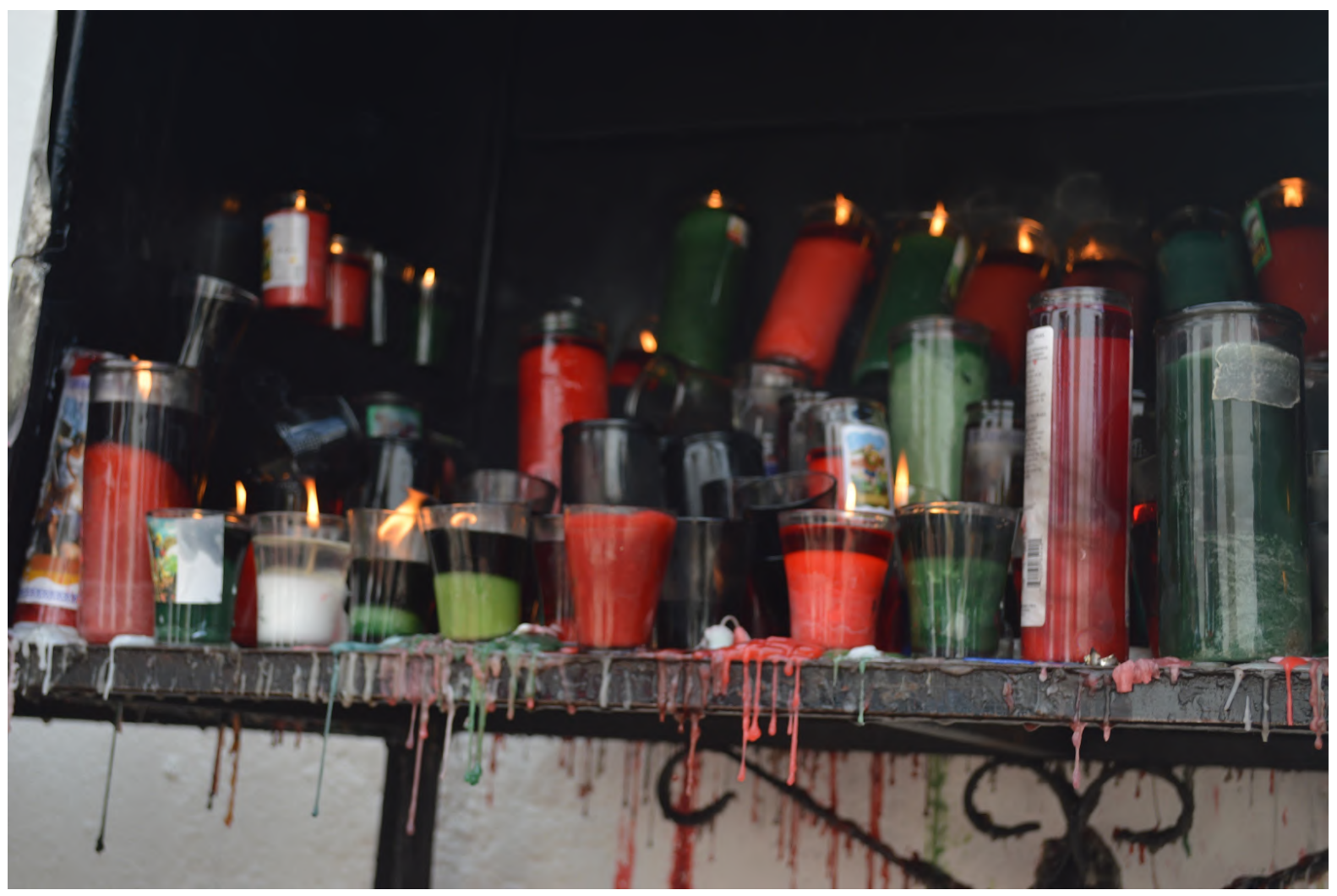

Foto 6: Pedidos e preces viram cera quente. Fonte: Acervo do Autor, 2017.

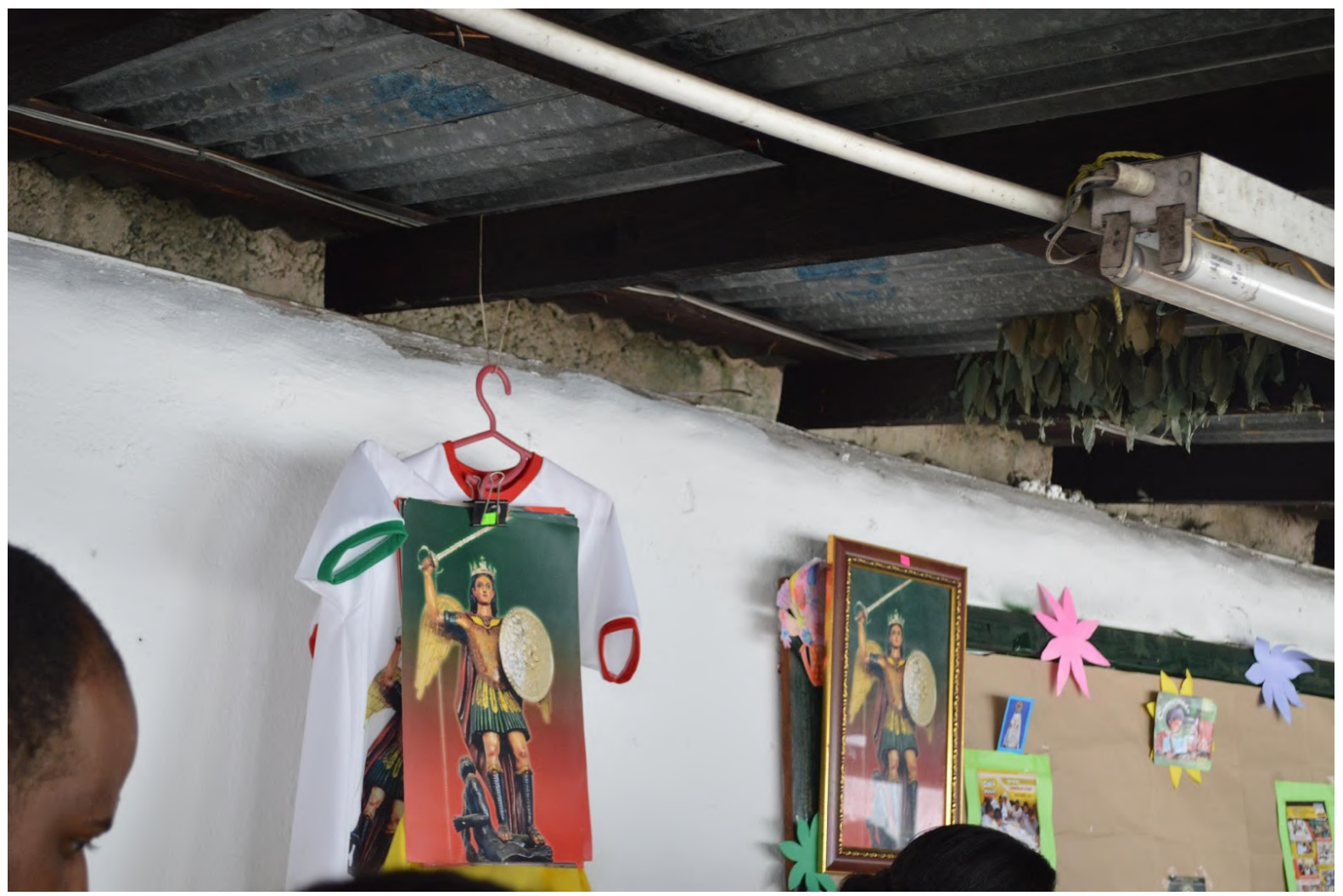

Foto 7: Suvenires vendidos na sacristia da igreja de San Miguel com réplicas da imagem do santo que se encontra dentro da igreja. 


\section{As festas para San Miguel: velas e composições (est)éticas}

Na tarde do dia de San Miguel, eu e Sandra combinamos de ir a uma festa organizada por uma servidora de mistérios (amiga dela) em uma das cidades que compõe a zona metropolitana de Santo Domingo, Nígua. Para ir até lá, conseguimos, por acaso, a carona de um conhecido de Sandra que encontramos na manhã da festa e que sabia que ela poderia sugerir boas festas a San Miguel ${ }^{12}$ - o arquiteto Eduardo. No meio da tarde, encontramos ele e fomos em direção à Nígua, que fica no lado oeste da capital. Eduardo gosta de frequentar o máximo de festas a santos o possível porque lhe agradam os palos (como são chamados os tambores) e sempre há boa comida e bebida.

Quando chegamos a Nígua, duas horas depois devido ao trânsito, descobrimos que a amiga de Sandra só faria sua festa para o santo no dia seguinte. No entanto, ela nos indicou outra servidora de Belié, que teria sua festa naquele dia e morava perto de sua casa, a senhora Mariana. Após atravessarmos algumas quadras, chegamos à casa dela, que tinha alguns carros estacionados em frente e algumas pessoas na varanda. Nos aproximamos, perguntando se aquela era a casa de Mariana e rapidamente uma mulher de meia idade se levantou e confirmou que era ela. Após entrarmos e nos apresentarmos brevemente, ela explicou que estava de saída para a festa de um advogado que ela atende e que nós éramos bem-vindos a acompanhá-la ${ }^{13}$. Eu e Sandra agradecemos e então lhe explicamos a sorte que tivemos em encontrá-la saindo - já que nem imaginávamos poder ir até lá. Ela respondeu muito calmamente que San Miguel havia nos levado até ela e que não se tratava de um acaso, pois chegáramos justo na hora de ir para a festa.

Saímos em uma caravana de carros em direção ao que seria o norte da capital, passando por vielas estreitas e estradas antigas, e nos encaminhamos para o subúrbio de outra cidade, Manoguayabo - também lindeira com Santo Domingo. A casa ficava num pequeno e íngreme vale, em uma região afastada de movimento. Aliás, o melhor seria chamá-la de residência, pois era uma edificação composta por três grandes casas, com uma grande piscina e um espaço para festas. Foi nessa parte que ficamos todo o tempo. Já na entrada, havia uma enorme imagem, certamente a maior que eu vi, de San Miguel ao lado de Santa Ana ou Anaísa Pié - a esposa de Belié Belcan. A festa estava começando e havia uma grande expectativa para a chegada dos paleiros ${ }^{14}$, alguns dos melhores, segundo Sandra, que os conhecia de outras festas para santos.

$\mathrm{Na}$ parte de trás da casa, depois da piscina, havia uma pequena sala que brilhava de longe. A porta desta sala era feita de ferro trançado, deixando brechas como uma grade. Ao nos aproximarmos, vimos diversas imagens de santos, velas de todas as formas e cores, e tivemos a sensação de que dali saía um calor inexplicável. Foi a primeira vez que vi - provavelmente todos - os santos e entidades que compóem

12 Nos dias anteriores eu havia combinado com ela que não tentaríamos ir a alguma destas festas pois teríamos que voltar em transporte público à noite ou de madrugada, o que seria praticamente impossível, dado que o acesso às regiões afastadas é sempre difícil, e mesmo que fossemos de táxi, a volta seria imprevisível.

13 Conforme a própria Mariana nos explicou, esse advogado representa diversos bancos da capital em processos litigiosos.

14 Paleiros são tocadores de palos (tambores). Existem grupos que tocam profissionalmente, cobrando pela música em eventos particulares, que também tocam em eventos culturais. No entanto, me parece que a maioria dos paleros, são pessoas que têm outros trabalhos. Na região de Haina e Nígua (cidades costeiras na região metropolitana da capital), muitos estivadores do porto tocam em festas para santos e mistérios - mas o fazem como parte de um legado familiar - ponto que não irei explorar neste artigo. 
as 21 divisões do Vodu dominicano (como se diz em espanhol, la veintiuna división), reunidos em um só lugar. A sala não foi frequentada pelos convidados da festa, por estar em um lugar mais reservado. $\mathrm{O}$ foco eram os tocadores, que demoraram pelo menos uma hora para chegar. Ao chegarem, se reuniram rapidamente em frente ao bolo preparado para San Miguel - não puderam subir ao palco montado sobre a piscina pois acabara de chover. Assim, logo após um deles, cujo tambor feito de tronco era o mais grosso, acender uma vela ao centro da roda e começar a marcar o ritmo, a música passou a embalar os convidados com a salve: "San Miguel, San Miguel! San Miguel dáme tu espada pa vencer!"

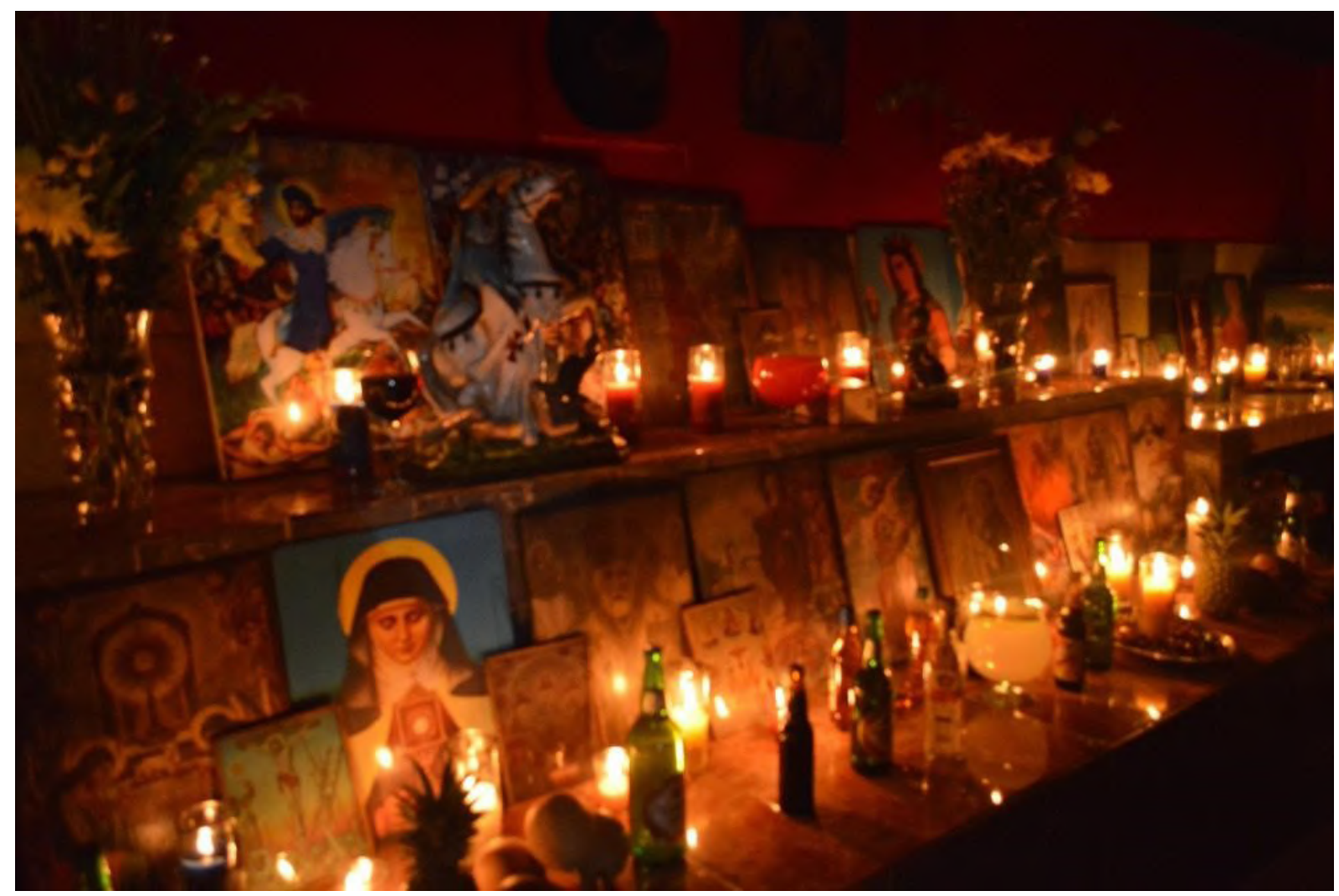

Foto 8: A sala de santos da casa do advogado. Fonte: Acervo do autor, 2017.

As velas, que iluminam e conectam seres humanos a outros planos, passaram a ser usadas em cultos católicos após a adoção oficial da religião pelos romanos. Muitas definições e constrangimentos foram criados para o controle do seu significado (como no ano de 1917, a mandatória que exigia que as velas usadas em missas fossem feitas da cera de abelhas), mas isso não só não garantiu o cumprimento, como perdeu força nas últimas definições do código canônico. Nesse texto, elas ocupam distintas paisagens - com variedade de sentidos, além da função básica de acesso ao divino. Na festa do advogado dominicano, a produção exigiu pouco das velas e mais da bebida e da comida oferecidas aos convidados como sinal de agradecimento a San Miguel e do pedido para que a proteção continuasse.

Assim, entender o que significa a festa para a vida na República Dominicana é saber que a pluralidade de sentidos se espelha também na pluralidade de festas privadas ao santo. O espaço da igreja, repleto de velas coloridas, principalmente em verde e vermelho, expressam a entrada que esses objetos/

15 Conforme me explicou o líder do grupo de paleros, a vela os conecta com os espíritos. Não é possível tocar para Belié Belcan sem que haja uma vela acesa. 
coisas têm. Se por um lado a quantidade de pedidos e orações valoriza e fortalece o santo, por outro, a contínua tentativa de expurgar a presença do vodu nas dependências da igreja - pelas velas e pelos devotos vestidos com as cores do santo - pressupõe a possibilidade de se produzir uma versão única do santo. Os pedidos estão diretamente relacionados a problemas do cotidiano e à vida profana de mortais. Pode ser a proteção de um advogado que defende os poderosos bancos, de um policial ou ainda de um traficante de drogas. Pode ser a garantia de que um filho consiga imigrar para os Estados Unidos ou a defesa contra a vizinha que inveja as benesses que se adquiriu ao longo da vida.

No trabalho de Alline Torres Dias Cruz (2014:52-53), esta função ordinária das relações com santos/mistérios do vodu ganha maior profundidade quando se leva em conta o sentido de serviço. Essa relação influencia a sua constituição enquanto pessoas. Na sua pesquisa, Cruz demonstra que ela (a relação com os mistérios) engendra fluxos de força (Cruz 2014:52). Esses fluxos compõem a 'circulação do dom' entre dominicanos em Porto Rico - o fazimento de família, pessoa e dom, e o serviço contínuo que essas relações demandam. Apesar de não poder me endereçar a essas questões diretamente, foi a partir do trabalho de Alline Cruz que compreendi a importância das velas (Cruz 2014:81-84) no cotidiano com os santos. Manter velas sempre acesas é um modo de alimentar a relação com eles.

O foco nas velas e sua importância informam as percepções a respeito da estética/ética contida nas relações e nas produções de significado. Há uma ressonância aqui com as preocupações de Michael Lambek a respeito de "éticas ordinárias" ou, ainda, da importância de coisas e objetos na manutenção dessas éticas onde coabitam e coexistem seres, tempos e planos distintos (Lambek 2010; Lambek 2002). Porém, não é minha preocupação traduzir ou realocar estas compreensões dentro do complexo esquema da filosofia ocidental sobre a ética - é o caso de tomar o termo de modo mais esvaziado, como uma etiqueta.

No meu entendimento, estou seguindo aquilo que o visível informa. As imagens do passado na relação com cultos negros/afro-caribenhos (as leis do Código Carolino e da constituição no período da ditadura trujillista) e as diferenças e proximidades entre servidores de mistérios e a Igreja Católica são constitutivas dos sentidos da(s) Festa(s) de San Miguel, pois não há somente uma festa.

Dentro do espaço da igreja, as velas são pedidos e intenções, mas também iluminam o grande altar. Fora dela, alimentam o fazimento diário de relações e a manutenção da força de San Miguel/Belié Belcan - como alimento da relação com os mistérios e a luz que acende os tambores. Se não fosse essa força, é bem provável que a festa ao santo se reduzisse a um pequeno festejo de bairro. Esse movimento anual que faz a festa ser famosa entre os dominicanos interessa também à igreja - as pessoas lotam as missas e contribuem como podem com o dízimo, mas sempre contribuem. Servidores de mistério costumam ir às missas, apesar de se sujeitarem aos sermões que não os reconhecem como portadores de crenças legítimas. Afinal de contas, seu dom de receber mistérios veio de Deus - o criador, cultuado dentro da igreja. Os deveres impostos pelo dom são atos orientados pelas éticas próprias das relações do vodu (ou a ética cotidiana da relação com cada santo). Elas transcendem os controles ou preceitos da Igreja Católica e se materializam nas velas e velones, nos panos e cores, dando forma às festas ao santo. A estéti- 
ca conflituosa destas relações não deve se deixar levar por seu aspecto carregado. Ela não é uma confusão e sim uma profusão de elementos ordenados segundo as necessidades dos sujeitos em transformação ${ }^{16}$.

A transmissão/circulação de forças, mesmo sob conflitos (ou sob a acusação de externalidade de um componente por outro), reitera a importância e a força de San Miguel e demonstra indícios das variações internas ao vodu. É interessante lembrar a máxima de Edmund Leach (inspirado por Wittgenstein) a respeito dos rituais da Alta Birmânia: "Logicamente, estética e ética são idênticas" (2014:75). É importante, no entanto, guardar o seu complemento:

$\mathrm{Na}$ origem, os pormenores do costume podem ser um acidente histórico; mas para os indivíduos que vivem numa sociedade tais pormenores nunca podem ser irrelevantes, são parte do sistema total de comunicação interpessoal dentro do grupo. (Leach 2014:75).

A compreensão sensível do antropólogo britânico não deixa de ser relevante, apesar de aqui parcialmente descontextualizada, para sugerir que talvez se deva olhar para as velas sob outra perspectiva. Como mais recentemente colocam Henare, Holbraad e Wastell (2007:12) com respeito às coisas, há que se levar a sério o que parecem modulações metafóricas de nossos interlocutores para começar a entender seus mundos.

É especialmente relevante a forma como esses autores apontam a necessidade de se suspender a distinção ontológica entre conceitos e coisas e de se assumir um construtivismo radical, tal como o fazem Gilles Deleuze e Félix Guattari. Aliás, as velas no vodu dominicano, em suas propriedades e operações, se aproximam da definição de conceito desses dois filósofos: remetem a outros conceitos, planos e multiplicidades não só históricos, mas em devires e conexões presentes; seus componentes são inseparáveis nele (a cera e o pavio fazem o que é a vela - fora dela não são); são pontos de coincidência, condensação ou acumulação de seus próprios componentes (as velas são também a intensividade das intenções que as acendem) (Deleuze e Guattari 2010:27-28).

Há, no entanto, um limite para essa leitura. Nem sempre as velas são coisas-conceito no sentido amplo trazido acima. No catolicismo, elas ainda operam enquanto objetos numa relação clara com as intenções que não abrem mão da cesura entre sujeitos e objetos ${ }^{17}$. No ambiente da festa, o espaço das velas na igreja se preenche, portanto, de objetos e coisas. Umas queimam as intenções como devido, outras transbordam ou vazam, ocupando a superfície em seu entorno (Ingold 2012:29).

Volto a como cheguei ao Fray Francisco, ainda na minha primeira estada em campo, de modo a evidenciar outras leituras sobre os caminhos que percorri e o trânsito de praticantes do vodu na Igreja.

16 Em consonância com uma ou um dos pareceristas deste artigo, ressalto que o território sob domínio espanhol na ilha sofreu um relativo abandono da metrópole após a descoberta do ouro no México, além da expansão ao sul. O mesmo se pode dizer com relação à presença da Igreja ou pelo menos sua força nesse território. Após a Revolução Haitiana, a escravidão foi abolida em toda a ilha. Certamente, esse foi um momento em que se pode considerar que houve uma condescendência/negociação da parte do complexo Estado/Igreja com as práticas negras ou africanas. Um período crucial para o que resulta ser posteriormente a estética do vodu.

17 Para uma leitura etnograficamente informada do debate sobre a distinção entre objetos e coisas, e suas efetuações no universo do catolicismo, ou como operam as cesuras diante da possibilidade de se estar lidando com intenções maléficas (advindas do diabo), ver a brilhante reflexão de Ypuan Garcia (2018:266-269). 


\section{Passeio no Mercado Modelo}

Apesar das muitas contraindicações por ser um estrangeiro branco, no dia 22 de fevereiro de 2017 fui ao Mercado Modelo, que como a igreja de San Miguel, está nas franjas da Zona Colonial em Santo Domingo (ver o mapa acima). O mercado é, ou foi, um local para a compra de suvenires turísticos. Subindo as suas escadas, fui abordado diversas vezes pelos donos das lojas da entrada. Uma vez dentro, a cada passo que dava, ouvia convites, quase convocações, para entrar nas diferentes, mas muito parecidas, lojas/ bancas do local. Apesar de a fachada parecer algo semelhante às de mercados municipais no Brasil, sua estrutura interna era precária e as divisórias entre cada vendedor eram irrisórias e confusas. Decidi caminhar até o final para ver o que havia lá e por fim sair, pois não estava interessado em comprar suvenires.

Ao chegar aos fundos do Mercado, próximo a um vendedor de quadros muito semelhantes aos vendidos no centro da zona colonial, avistei no canto direito uma placa "banca San Miguel" e diversas imagens de santos ao redor dela. Pensei comigo mesmo que ali haveria de encontrar algo interessante. Após conversar brevemente com a dona, ela negou saber qualquer coisa sobre o vodu e disse que me levaria no lugar onde estava o que eu buscava. Me chamando para os fundos de sua banca, ela me levou ao interior da estrutura do mercado, ainda no lado direto - onde se via mais claramente a precariedade da construção -, para chegar a um lugar repleto de ervas, folhas de distintos tamanhos e cores amontoadas, além de velas de várias cores. Santos e mistérios agora me recebiam na banca/botânica ${ }^{18}$ Belié Belcan de Doña Elena.

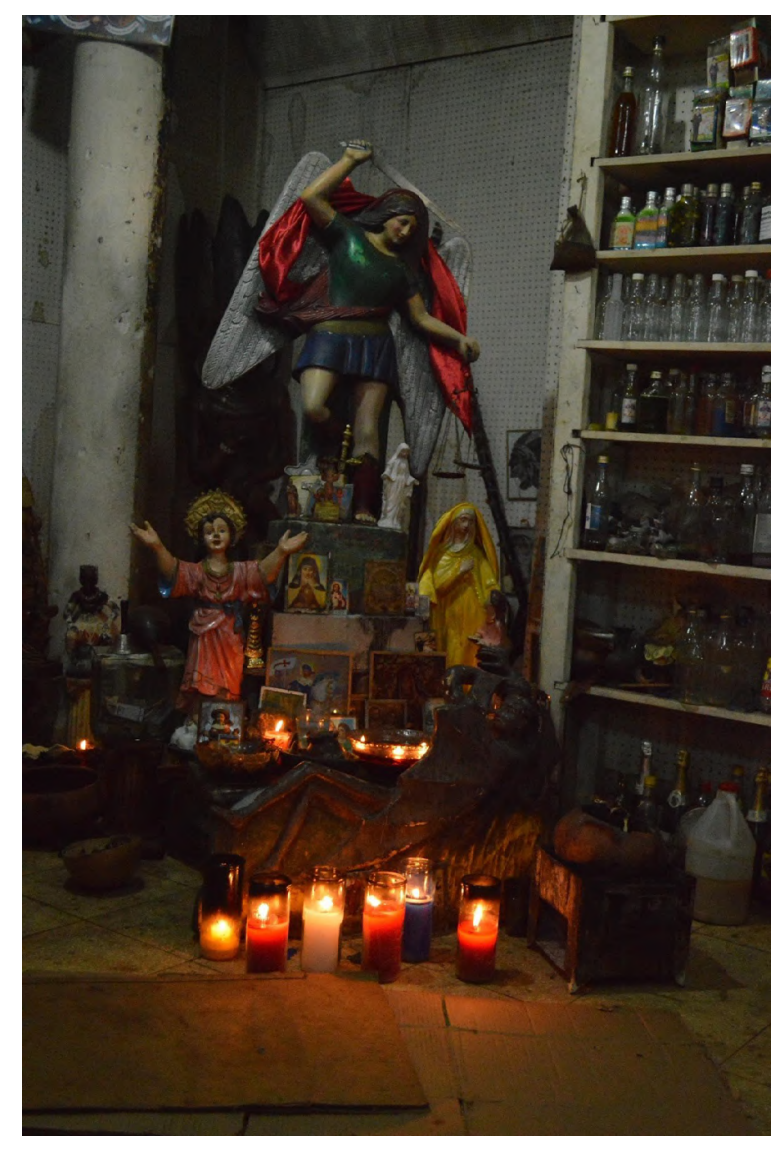

Foto 9: Altar de Doña Elena. Fonte: Acervo do Autor, 2017.

18 Sobre as botânicas, ver Cruz (2014). 
Essa senhora me recebeu enquanto lavava garrafas - e ao me ver prostrado em frente ao seu grandioso altar, disse que eu poderia tirar fotos se quisesse. Aproximadamente uma hora depois, chegou um conhecido seu que, depois de pedir um gole de café, acendeu um charuto enquanto conversava com ela. Ao me ver com a câmera na mão, perguntou se eu era jornalista ou fotógrafo e expliquei que era pesquisador e que vinha do Brasil. Tomás, como o chamarei aqui, foi muito receptivo e me explicou que era o guardião daquele altar. Ele me explicou parte da cosmologia do vodu dominicano e a gênese de San Miguel, como arcanjo guerreiro. Me perguntou se eu era católico e, quando confirmei que tive uma formação católica, me disse que para lidar com as coisas do vodu era importante que eu fosse à missa, de modo a evitar que coisas ruins acontecessem comigo. No meu caderno de campo anotei:

\begin{abstract}
A base de sua leitura é de que tudo provém de Deus, isso reconhecido, há que se levar em conta que existe um mundo espiritual, com espíritos, anjos, semi-Deuses que há milhares de anos conviveram com os humanos. Seres extra-humanos. Nós não podemos vê-los mais pois aos poucos o homem foi se afastando desses seres e pelas suas criações (que na verdade são de Deus) perdeu a sensibilidade para o contato com eles. O mundo espiritual por sua vez contém uma série de dimensões as quais não podemos nem imaginar em forma, número e conteúdo. Ele me explicou que os animais em geral tem três olhos, pois são seres sensitivos, enquanto apontava o cachorro que agora se movimentava em cima da bancada - foi quando percebi que havia como três gatos circulando na banca. Voltando a sua explicação, e ao lugar de San Miguel, disse que ele é o líder das tropas divinas, de anjos, e que ele foi importante no momento em que Lúcifer, que controlava o conhecimento, se rebelou contra Deus. Com isso me explicou que os primeiros Beliés eram guerreiros/ semideuses/espíritos que foram identificados com San Miguel devido a diversos processos históricos, envolvendo a Inquisição, e o controle dos saberes espíritas pelos franceses, e que a existência de vários Beliés se deve a pertenças que foram se repartindo e reproduzindo por parentesco. Diversos Beliés têm diferentes personalidades.
\end{abstract}

A complexa leitura de Tomás abria uma primeira experiência com relação a San Miguel. A afirmação de que haveria múltiplos Beliés confirmou que não se trata de simples representação, mas da ação de outros seres em outros mundos, outras ontologias. Quando lhe contei, ao final daquela tarde, que iria para a missa na Igreja de San Miguel, ele disse que me acompanharia. Saindo da Botânica, encontramos com uma amiga sua e passamos em uma loja, também pertencente ao mercado. Ele parou para comprar três velas em uma loja repleta de velas coloridas e produtos para vodu dominicano: uma azul, uma branca e outra vermelha. Ao chegarmos à igreja, que ficava a uma quadra dali, ele pediu que escolhêssemos qual vela acenderíamos - eu optei pela branca, a moça pela azul e ele pela vermelha. Segundo nos explicou, as cores falavam também sobre nossa personalidade - no meu caso, a de uma pessoa pacífica. Naquele dia, ao final da missa, Tomás me levou à sacristia para conhecer o Fray Francisco e agendar um horário para entrevistá-lo. 


\section{Notas conclusivas}

Procurando levar a sério os entendimentos que me foram transmitidos, parece inevitável perceber as ações de San Miguel, como me explicou acima a senhora Mariana, no controle dos meus caminhos pela sua festa. No dia posterior ao da festa (30/09/2017), por exemplo, fui a mais um festejo junto com o arquiteto Eduardo, onde passamos o final da manhã e o início da madrugada, ao som de palos, comendo, bebendo e observando as pessoas receberem atendimentos de uma servidora de mistérios ou de Belié Belcan. Meses antes, quando acendi uma vela branca na igreja, junto com Tomás, eu havia pedido ao santo que me protegesse e guiasse para o bom sucesso da pesquisa.

As velas, por sua vez, são os vasos comunicantes entre o mundo católico-nacional e os mundos do vodu. São rastros históricos, mas também a via de acesso a esses mundos. Assim me definiu o tocador de palos, assim me introduziu Tomás, e dessa mesma forma se definiu o incômodo presenciado no dia da festa. É claro que outros elementos fazem parte desta composição - o rum, o tabaco e os tambores, que se bebe, se traga e se escutam. Porém, as velas que transbordam em cera parecem elas próprias transbordarem os limites do espaço destinado a elas e, a seu modo, pintam as dependências da igreja com as cores de Belié. Em contraste, no cotidiano, o uso delas é módico o suficiente para manter a relação com o santo e alimentar os mistérios. Ainda assim, não pretendo com isso definir qual é o limite entre esses mundos, mas posso explorar a externalidade de que me falava o Fray Francisco em dois tipos de leitura.

Penso que o caráter externo das velas coloridas, assim atribuído pelo Fray, possa ser explicado pela longa duração da distinção ontológica a qual Trouillot se refere (1995:76) - resultado de compreensões do mundo que têm sua origem na renascença, na qual se hierarquizam subjetividades, conforme se vê na normativa do Código Negro. O mesmo autor se debruça sobre tal distinção para demonstrar que ela se torna mais e mais complexa à medida que se consolida um pensamento moderno. A multiplicidade de representações do 'selvagem' em relatos de viajantes e obras literárias vai se reduzindo à proporção que o próprio pensamento ocidental se ordena e subdivide suas funções (Trouillot 2003:17-18). A compreensão e reprodução dessa representação fica a cargo do que se convenciona como antropologia no século XIX. As diversas críticas a essa representação achatada ao longo do desenvolvimento da disciplina têm diferentes faces e sentidos. Uma delas, que reclama a necessidade de retomarmos tais diferenças ontológicas, sem hierarquizá-las (Viveiros de Castro 1998:92), se volve consoante ao esforço de Trouillot em descolonizar o trabalho antropológico. Por isso, é mister retomar a leitura de Joan Dayan, que diz que as práticas do Vodú não se opõem ao Ocidente ou mesmo ao cristianismo. O mesmo vale para aqueles que o praticam. A forma criativa ou ativa pela qual se apropriam, indigenizam ou inventam as velas do catolicismo não é mera resposta aos controles do complexo Estado/Igreja dominicano, é também um modo de transformar o ocidente. Aliás, conforme apresentei acima, essas expressões têm também suas diferenças internas (as 21 divisões e/ou as variações do Vodou haitiano, que tem outras vertentes) e, como me explicou Tomás, elas se reportam às historicidades e aos planos indiscerníveis para os católicos. 


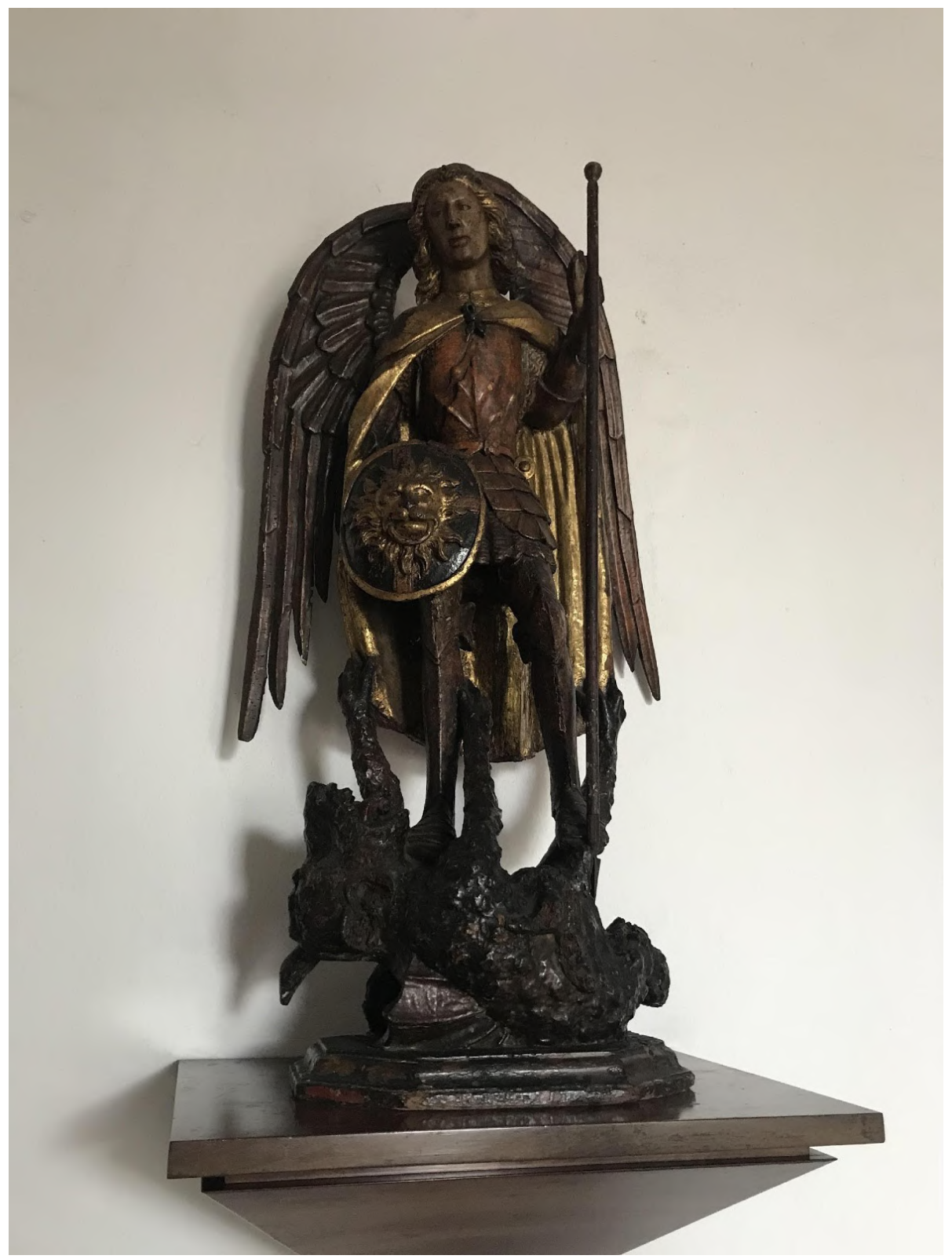

Foto 10: A provável primeira imagem de San Miguel da ilha de Hispaniola, na casa de Diego Colombo, filho de Cristóvão Colombo, aproximadamente no século XVI ou XVII.

Fonte: Acervo do autor, 2018.

Por outro lado, essa externalidade das velas coloridas pode informar também um jogo "espacial", de aproximação e afastamento. Um jogo ou movimento interessante que se observa na presença tão próxima de Lucas, sua festa e sua casa à frente da Igreja. A figura do santo que não se descola do mistério, transforma as práticas do catolicismo popular dominicano - ainda que sem os auspícios de alguns sacerdotes, ou produzindo o afastamento de outros. Tudo se passa como se, no dia da festa, a comemoração ao santo permitisse uma aceitação da contiguidade e esses marcadores de externalidade e diferença se percebessem mais pela variação na intensidade cromática que velas - mas também runs, charutos, bolos em verde e vermelho, roupas e etc. - produzem do que por uma aplicação de fato das dogmáticas clericais e estatais. Como bem observa Michael Taussig (2006:32), a palavra cor, no seu 
sentido etimológico, está ligada ao ocultamento e, nesse contexto, eu diria que ela opera cromo-topos, de modo que as cores, em sua variação de intensidade, formam um gradiente inevitável que ora oculta, ora revela durações, permanências e relações ${ }^{19}$. Essa cromotopia se efetua dinamicamente na Zona Colonial, mas também em espaços de antigos engenhos de açúcar e portos, onde hoje está a região metropolitana da capital da República Dominicana. Talvez aí esteja o transbordamento que transforma esteticamente vodu e catolicismo e onde outras leituras possíveis residem.

Assim, as cores verde e vermelho, que pintam também os adornos do brasão do exército, marcam poderosas coexistências temporais, ontológicas e cosmológicas, intangíveis sob uma luz qualquer, mas que se volvem imanentes à luz das velas.

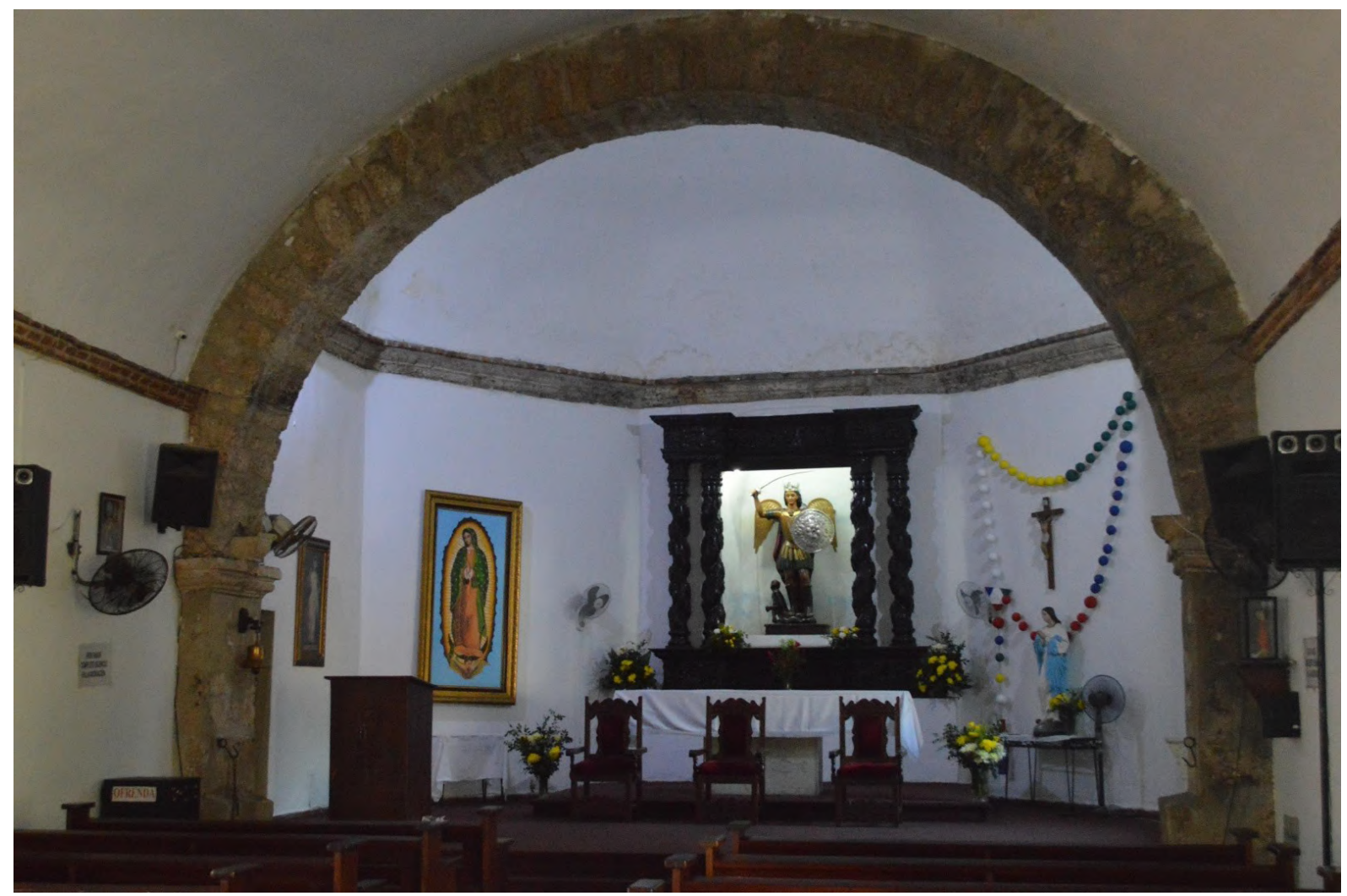

Foto 11: Interior da Igreja de San Miguel em um dia de semana. Fonte: Acervo do autor, 2017.

Victor Miguel Castillo de Macedo é mestre em Antropologia pela UFPR e doutorando no PPGAS/Museu Nacional (UFRJ). É membro do Laboratório de Antropologia e História-LAH, Professor do Instituto Federal do Paraná (IFPR) e ex-Visiting Fellow do Dominican Studies Institute.

\footnotetext{
19 Agradeço a John Collins tanto pela indicação da reflexão de Taussig sobre as cores quanto por sugerir o termo cromotopos ao comentar este texto, em um jogo com o termo homófono de Bakhtin, com Collins, comunicação pessoal, (2019). Recomendo ainda, outra análise na qual as cores operam diferenciações em contextos rituais afro-caribenhos, em Brackette Williams (1990).
} 


\section{REFERÊNCIAS BIBLIOGRÁFICAS}

ANDÚJAR, Carlos. 2007. Identidad cultural y religiosidade popular. Santo Domingo: Editorial Letra Gráfica.

BARCELO, Javier Malagon. 1974. Código Negro Carolino (1784). Santo Domingo: Ediciones de Taller.

CRUZ, Alline Torres Dias da. 2014. Sobre dons, pessoas, espiritos e suas moradas. Tese (Doutorado em Antropologia Social). Rio de Janeiro, RJ: Universidade Federal do Rio de Janeiro.

DAVIS, Martha Ellen. 1996. Vodú of The Dominican Republic. Indiana: Ethnica Publications.

DAYAN, Joan. 1995. Haiti, History, and the Gods. Los Angeles: University of California Press.

DEIVE, Carlos. 1988. Vodu y Magia en Santo Domingo. Santo Domingo: Fundación Cultural Dominicana.

DELEUZE, Giles; GUATTARI, Félix. 2010. O que é a filosofia?. São Paulo: Editora 34.

GARCIA, Ypuan. 2018. Formas de "buscar Deus" e ser assediado pelo demônio: objetos na vida de católicos brasileiros. Etnográfica. 22(2): 259-280.

HENARE, Amiria, HOLBRAAD, Martin, WASTELL, Sari. 2007. Introduction. In: Henare, A. Holbraad, M. Wastell, S. Thinking through things: theorising artefacts ethnographically. London, UCL Press. HERSKOVITS, Melville. 1971. Life in a Haitian Valley. New York: Anchor Books.

INGOLD, Tim. 2012. Trazendo as coisas de volta à vida: emaranhados criativos em um mundo de materiais. Horizontes Antropológicos, 18 (37): 25-44.

KEANE, Webb. 2005. Signs are not the Garb of Meaning: On the Social Analysis of Material Things. In.: D. Miller (ed.). Materiality. Durham/London: Duke University Press.

LAMBEK, Michael. 2002. The Weight of the Past: living with history in Mahajanga, Madagascar. New York: Palgrave MacMillan.

, 2010. Introduction. In: M. Lambek (ed.) Ordinary Ethics. New York: Fordham University Press.

LEACH, Edmund. 2014 [1964]. Introdução. In.: Sistemas Politicos da Alta Birmânia. São Paulo:

Editora da Universidade de São Paulo, pp.65-81.

MÉTRAUX, Alfred. 1958. Le Vadou Hä̈tien. Paris: Éditions Gallimard.

PRICE-MARS, Jean. 1953. La Republique d'Haïti et la Republique dominicaine: Les aspects divers d'un problème d'histoire, d'géographie et d'éthnologie. Tome II. Port-au-Prince: Collection du Tricinquantenaire de l'Indépendence d'Haïti.

RAMSEY, Kate. 2011. The Spirits and the Law - Vodou and Power in Haiti. Chicago: The University of Chicago Press.

STRATHERN, Marilyn. 2014. Artefatos da história: os eventos e a interpretação de imagens. In: M. Strathern. O efeito etnográfico e outros ensaios. São Paulo: Cosac Naify, pp.211-230.

TAUSSIG, Michael. 2006. What colour is the sacred? Critical Inquiry, 33 (1): 28-51.

TEJEDA ORTIZ, Dagoberto. 2013. El Vudú en Dominicana y en Haiti. Santo Domingo: Ediciones Indefolk, Colección Dagoberto Tejeda. 
TROUILLOT, Michel-Rolph. 1995. Silencing the Past: power and the production of history. Boston: Beacon Press.

, M. 2003. Anthropology and the Savage Slot: The Poetics and Politics of Otherness. In: M. Trouillot. Global Transformations: Anthropology and the modern world. New York: Palgrave MacMillan.

VIVEIROS DE CASTRO, Eduardo. 1998. Supernature: under the gaze of the other. In: Viveiros de Castro, Eduardo. Cosmological Perspectivism in Amazonia and elsewhere. Four lectures given in the Department of Social Anthropology. Cambridge: HAU Master Series.

WILLIAMS, Brackette. 1990. Ducthman Ghosts and the History Mystery: Ritual, Colonizer, and the Colonized interpretations of the 1763 Berbice Slave Rebellion. Journal of Historical Sociology. 3(2): 133-165.

WOLF, Eric. 1958. The Virgin of Guadalupe: A Mexican National Symbol. The Journal of American Folklore. 71(279): 34-39.

\section{REFERÊNCIA DAS IMAGENS}

Zona Colonial de Santo Domingo. 1992. Archivo General de la Nación (AGN), DO Archivo General de la Nación Mapas Gaar/ 1.1.1.02. Disponível em: http://colecciones.agn.gob.do/opac/ficha. php?informatico=00098914SS\&codopac $=$ OUCAR\&idpag=1342787271\# Acesso em: 7 de julho de 2019. 


\section{Velas e Velones: SObre estética e materialidade entre Catolicismo E Vodu na República Dominicana}

Resumo: Neste trabalho, exploro a multiplicidade de papéis e sentidos que coisas e seres não-humanos contêm em festas de religiosidade popular na República Dominicana. Tomo como ponto de partida as controvérsias que se passaram durante um trabalho de campo sobre a Fiesta de San Miguel em torno das velas e dos velones (velas grandes), que se diferenciam por cor e tamanho. O pano de fundo para essa breve reflexão é o enunciado que opõe catolicismo e vodu, sobre o qual eu argumento que objetos/ coisas, formas e cores circulam, mobilizam e articulam sentidos e valores que tornam mais complexa tal oposição. Também caracterizo a intensidade e a duração temporal dessa fricção em outras épocas e registros. O objetivo é demonstrar de que maneira elementos sensíveis e estéticos alimentam uma contiguidade entre os polos dessa antinomia, que termina por fortalecer San Miguel como santo e mistério na compreensão dominicana.

Palavras-Chave: Catolicismo Popular; Vodu Dominicano; Materialidade.

\section{CANDLES AND “VELONES": ON AESTHETICS AND MATERIALITY BETWEEN CA- THOLICISM AND VODOU IN THE DOMINICAN REPUBLIC}

Abstract: In this work, I explore the multiplicity of roles and meanings that things and no-human beings contain in popular religiosity celebrations in the Dominican Republic. I take as a starting point controversies that took place during fieldwork at Fiesta de San Miguel relating to candles and velones (big candles), which differ in color and size. The context of this brief reflection is the stated opposition between Catholicism and Vodu, which I develop arguing that objects/things, forms, and colors circulate, mobilize and articulate senses and values that make such an opposition more complex. I also characterize the intensity and the temporal duration of this friction during other epochs and registers. The main goal is to demonstrate how sensitive and aesthetic elements feed contiguity between the two poles of this supposed antinomy, which ends up strengthening San Miguel as both a saint and a mystery in the Dominican vision.

Keywords: Popular Catholicism; Dominican Vodu; Materiality.

RECEBIDO: $18 / 02 / 2019$

APROVADO: $30 / 06 / 2019$ 